Portland State University

PDXScholar

6-16-2021

\title{
Queer: A 25 Year History, A Blooming Identity
}

Greer Klepacki

Portland State University

Follow this and additional works at: https://pdxscholar.library.pdx.edu/honorstheses

Part of the Feminist, Gender, and Sexuality Studies Commons Let us know how access to this document benefits you.

\section{Recommended Citation}

Klepacki, Greer, "Queer: A 25 Year History, A Blooming Identity" (2021). University Honors Theses. Paper 1092.

https://doi.org/10.15760/honors.1119

This Thesis is brought to you for free and open access. It has been accepted for inclusion in University Honors Theses by an authorized administrator of PDXScholar. Please contact us if we can make this document more accessible: pdxscholar@pdx.edu. 
Queer: A 25 Year History, A Blooming Identity

by

Greer Klepacki

An undergraduate honors thesis submitted in partial fulfillment of the requirements for the degree of Bachelor of Science in

University Honors

And

Communication

Thesis Adviser

Lisa Weasel

Portland State University 
QUEER: A 25 YEAR HISTORY

Abstract: The term "queer" has a long and complex history that has been previously undocumented in academic works. This thesis will work to unravel and uncover the complexity behind the term itself while also establishing its place in a historical timeline. In doing so, this thesis will illustrate the importance that queer identity has in the LGBTQIA+ community, along with academic, social, and theoretical frameworks. Furthermore, it will showcase the unique opportunity that the term queer has to allow its audience to engage with and understand a more critical and dynamic approach to the past, present, and future of the communities and world around them.

Keywords: Queer, Queer Theory, Feminist Theory, Social Science, LGBTQIA+ 
“We're here, we're queer, get used to it!" exclaimed ACT UP members in the 1990's marches for queer liberation (Bronski, p. 232, 2011). In 2018, queer activists, myself included, echoed this sentiment with the proclamation, “We're here, we're queer, we're fabulous, don't fuck with us!" down the streets of Portland, Oregon in the annual Transgender March during Portland Oregon's pride weekend. 'I like using the term queer because it just tells you I'm not straight (Stanger, 2019)" proclaims a sticker stuck to a telephone pole in the NE Portland Hollywood neighborhood.

These modern conceptions of queer have only recently evolved into this budding identity term. Before this moment, the word queer had a rather convoluted and sometimes tumultuous journey that led to several instances of revisions and co-opting both in society and for individuals. As early as the early 15 th century, the term queer served as an adjective that was synonymous with being odd, strange, or out of the ordinary. However, as time advanced, so did society, and the term queer morphed into a noun rather than an adjective that had previously functioned as a derogatory word used to name LGBTQIA+ folks. After the emotional, mental, and physical healing of the queer community that continues today, the late 19th century brought about the term queer as a reclaimed identity term by members of the LGBTQIA+ community (Merriam-Webster, 2021).

At this point, it must be noted, both for this thesis and field of research to acknowledge that queer is not used by every member of the LGBTQIA+ community as an identity term and that it has not been reclaimed by all people in this community. For some, it might still hold the generational trauma of being used as a slur. For others, it may not function as an inclusive term for their own identity. Even further, for some, queer may feel performative or not big enough to contain the multitudes of their identity. All of this establishes that for the scope of this thesis, the 
term queer will be employed as a reclaimed identity term and be applied to review history, queer theory, and the evolution of the term queer over the last 25 years. More specifically, this thesis will chronicle the history of the term queer over the last 25 years, since there is not a concrete, pre-existing academic essay on the history of the term queer. This thesis will work to bridge this gap in knowledge through a thorough literature review of already published literature in the last 25 years on the topic, along with comprehension and implementation of queer theory and other related fields of research, to establish queer as a relevant and important identity term in the 21 st century.

Before outlining this prolific history chronicle, it is important to establish a solid background on the word queer itself. As mentioned above, the term queer first appeared in the early 15 th century and denoted someone or something as odd, quirky, or out of the ordinary (Merriam-Webster, 2021). It wasn't until the early 19th century that the word queer began to function as a way to label LGBTQIA+ members of society (Keywords Project, 2016). With this new evolution of the term queer came a strong tendency to use the term queer as a derogatory way to identify LGBTQIA+ folks. In the spirit of queer resilience, the 1990s showcased the term queer as a reclaimed identity term by members of the LGBTQIA+ community to refer to themselves (Keywords Project, 2016; Perlman, 2016). While there is no exact way to record the first use of queer as an identity term, the 1990s showed some of the first popular and public use of the term in this way.

Queer identity, according to current researchers, “... is neither a statement nor a question yet it functions metonymically as both because its opacity encourages us to search for possible meanings within it, prompts us to ask questions about what those meanings might be, and 


\section{QUEER: A 25 YEAR HISTORY}

compels us to reflect on why we are driven to conduct a search for such meanings in the first place (Giffney \& O’Rourke, 2016)”.

Here, other researchers are helping to showcase the obvious, in that queer identity is complex and multi-faceted, and must not be taken through a reductive lens. Rather, queer identity should be looked at holistically and with a more expansive understanding of concepts such as queer theory, feminist theory, and identity as a whole conceptual framework.

An extension of this idea notes that queer identity does not simply hold one definition, but rather, “...has expanded beyond meaning only 'homosexual.' In fact, 'queer' does not have a single meaning, except perhaps 'not heterosexual...' Even the "Q" in LGBTQ could stand for either 'queer' or 'questioning' (Perlman, 2019)". This quote further points to the complexity of queer identity, in that not only is it purposefully ambiguous, but it also asks the people and communities interacting with it to bring a more open and expansive mindset.

Along with deconstructing reductive identity terms and instead employing expansive thinking, queer also helped to make space for and represent those who have historically been left out of history. Simply put, "LGBT history does not exist (Bronski, p. 3, 2011)". Queer history functions to decenter hegemonic and monolithic views of history that center cisgender, straight, and heteronormative experiences. In direct opposition and resistance, queer history works to be more inclusive and expand history to not only include, but also center, the experiences of those that did not fit into this historical narrative. Lastly, among many other things, employing queer onto history helps to illustrate the diversity in human experience and demonstrate history from a multitude of access points. The intentional omission of queer people from history not only oppresses and silences queer voices and experiences but also shapes and controls how society views their history and queer experience. This thesis will work to ensure that queer is employed 


\section{QUEER: A 25 YEAR HISTORY}

in history, as it is high time queer history and chronology are shared and given the attention and space it deserves.

Moving queer history into the 21 st century, the general focus of queer studies has shifted away from the history of the word queer, and instead into an exploration of queer theory, which, “...evolved as a reaction to the gay and lesbian rights movement in the USA in the 1970s and 1980s... (Barrett, 1997: 188; Jagose, 1996: 75-76, as cited in Motschenbacher \& Stegu, 2013)". Queer theory has become a necessary framework to look at history, as without it, a true understanding of queer history or the evolution of the term queer would be unattainable.

A fundamental component of queer theory that is necessary for an exploration of the word queer is that queer theory acts against hegemonic ways of thinking, works to dismantle monolithic ideas and images of society, and is critical of sexuality and social identities (Motschenbacher \& Stegu, 2013). This is bolstered by another main component of queer theory, which states, "[Queer theory] looks at, and studies, and has a political critique of, anything that falls into normative and deviant categories, particularly sexual activities and identities (Klages, as cited in Harris, 2005)"'. Today, modern theorists use queer theory to approach studying queer as both a word and social identity. This is often done by critical readings, reworkings, and reconceptualizing of already published works and social systems of gender, sexuality, and identities.

In addition to queer theory, this thesis largely hinges on feminist theory and how major concepts from this theoretical framework function alongside queer (theory). In previous research, it has often been cited that these two categories of theory diverge from one another and pertain to two different topics, rather than be utilized together (Glick, 2000). However, for the sake of this thesis, both queer and feminist theory will be utilized together to construct a deeper, more 


\section{QUEER: A 25 YEAR HISTORY}

intersectional approach to understanding queer history and linguistics. Historically, feminist theory has been constructed in sociology scholarship and defined as, “...a major branch within sociology that shifts its assumptions, analytic lens, and topical focus away from the male viewpoint and experience toward that of women...feminist theory shines a light on social problems, trends, and issues that are otherwise overlooked or misidentified by the historically dominant male perspective within social theory (Crossman, 2005)." In this decentering of the male experience, community members, scholars, and individuals have been able to recognize and emphasize the central role that non-male (in this case, women's experience, although there is more to be said about the reductive binary concepts taken from feminist rhetoric and theory) has in society.

At this point in the thesis, it cannot go unsaid that both this thesis's and societal definitions of feminist theory were largely birthed from the ideas and studies of Black scholars and feminists like bell hooks and Kimberle Crenshaw. While this thesis will be written through a queer and Latinx lens, it will undoubtedly be an imperfect explanation and incorporation of Black feminist approaches to theory and activism, but rather, be a deeply informed attempt.

Concepts of Black feminist theory like intersectionality, unique experience, and the importance of individual encounters with sexism must be incorporated into the conceptual framework of this thesis (Crenshaw, 2016; hooks, 1984). According to the prolific Black feminist scholars Kimberle Crenshaw and bell hooks, intersectionality refers to the literal and metaphoric intersections of a person's identity, and the unique pathways that inform the totality of a person's identity (Crenshaw, 2016; hooks, 1984.) A relevant example of this phenomenon applied to the early 1990's conceptualization of queer discussed below would be a unique and critical understanding of a person's individual lived experience, and how all of the social 


\section{QUEER: A 25 YEAR HISTORY}

identities they encompass and claim meet to form their single experience. In the early 1990s, queer communities were just beginning to understand and realize the relevance of Black feminist concepts to their own identities and communities; it wouldn't be until the 2000's that these concepts would be more critically understood and employed in queer communities and theory.

In addition to both queer and feminist theory, current research often cites linguistics, or the study of language, as an important site for queer theory and history cataloging. Presently, scholarship exists that focuses on the intersections of language and identity, thus creating a subfield of research, entitled queer linguistics. Queer linguistics, a rapidly evolving field of research, historically focused on how language and identity shaped one another. However, with the rapid expansion of society and identity, current research suggests that "....an analytic distinction between practice and identity is untenable (Hall, 2013)". With this newly crafted field of research, a clear distinction between society and identity must be drawn. In doing so, both language and identity can be understood in relation to one another, but not become conflated or confused with one another.

In employing queer linguistics, current research has now been able to apply and understand how language and identity shape one another within a queer context. Using queer theory, feminist theory, and queer linguistics, a history of the word queer can now be critically assessed and deepen the general understanding of queer identity as a whole.

Historically, the use of the term queer as a sexual identity can be traced as early as the 1990s, with the creation of, “....a positive self-label...group Queer Nation, whose goal was to fight back against violence perpetrated against queer folks (Perlman, 2019)”. The birth of this group helped to signal the beginning of the shift in the language of queer from an adjective into a reclaimed and empowered identity. Here, the term queer not only initiated a unified community, 


\section{QUEER: A 25 YEAR HISTORY}

but also a diverse identity category. Here, besides queer meaning more than one thing, it was also left intentionally vague and open to be more inclusive of all those who felt they would fit and belong within the queer label. With the unification of so many community members, new space had been forged for queer folks to meet and continue to work together against common oppressors while also understanding the unique difference in their individual lived experiences.

This instance marked an important evolution and distinction of the term queer. In actuality, this reclamation coincided with the wind-down of the mass amount of activism and resistance to oppression that occurred throughout the 1980s towards queer communities in response to the AIDS epidemic (GLSEN, 2016). This epidemic in particular disproportionately impacted queer people, especially gay men, as it was thought to be, "gay cancer (Killian, p. 8, 2014)". The disproportionate impact that the 1980's AIDS epidemic had on queer people led to the creation of several activist groups that focused on LGBTQ empowerment, such as ACT UP and later, Queer Nation (GLSEN, 2016; Perlman, 2019). The birth of such activist groups demanded evolution, diversity, and inclusion of people from all walks of life uniting against a common oppressor and pushed communities to expand themselves past those who shared identical experiences to themselves. In doing so, liberation became a focal point for LGBTQ activists, which later evolved into queer liberation. Queer liberation is, "still evolving rapidly," and has the goal to, "...educate others about oppression and work to eliminate that oppression (Myers, p. 14, 2013)”.

Even in the face of such strong oppression, queer people were still able to move their community towards liberation and empowerment. This push for equity and empowerment was not met without challenges, however. Oppressive forces such as denial of treatment for AIDS by the FDA, mass incarceration of activists at every march, and the loss of invaluable queer 


\section{QUEER: A 25 YEAR HISTORY}

comrades were only a fraction of what queer people sacrificed in the name of queer liberation in the 1980s into the early 1990s (Bronski, 2011).

Moving into the 1990s, there emerged an important emphasis on the role that neoliberalism played in queer liberation. Neoliberalism, “...offers 'freedom' as the core political goal, and the market as the site where that freedom might be realized (Weiss, p. 107, 2018)." Furthermore, "Neoliberal restructuring centers on the role of the state in the economy... the use of government spending and taxing to moderate the ups and downs of the business cycle; loosening or eliminating government regulation of corporate behavior in both the domestic and international spheres; privatization of government enterprises and public responsibilities; and large cutbacks in social programs (Kotz, p. 2003)." This shift signals that queer communities and activist groups were able to reconceptualize and reconfigure queer activism into a territory that was viewed in and by public audiences. This was demonstrated through the numerous public protests, peaceful sit-ins, marches, and rallies that were all held in the name of queer liberation (Bronski, 2011). Furthermore, neoliberalism centered queer voices in a capitalist and for-profit setting. This move not only amplified queer voices but also helped to center queer experience as an important and necessary component of the free market that non-queer people had already been a part of.

This shift towards neoliberalism does not stand without large critique from queer scholars, however. "Neoliberal ideology displays a special genius at making lopsided growth, wealth for a few, and immiseration for many more, seem sexy, progressive, and 'modern' (McRuer, 2011)." This criticism highlights the fact that this movement, while simultaneously allowing queer voices and experiences to become centered, also worked to commodify and further streamline queer experiences, which ultimately erased important differences and 


\section{QUEER: A 25 YEAR HISTORY}

inequalities within the queer community and experience itself. Moreover, this shift could even be seen as counterproductive to queer liberation, as it almost homogenized queer experience and identity to fit neatly into heterosexual society. This assimilation into heterosexual society had not been the singular focal point of queer liberation or activism; rather, protection, love, and appreciation into heterosexual society were more important for queer activists.

In addition to neoliberalism in the 1990s, direct action began to move closer to the forefront of queer activism. While this tactic was largely utilized in the 1970s and 1980s, marches and protests became even more popular in the 1990s. With this emphasis on direct action, more community-led and funded organizations began popping up across the nation. According to Urvashi Vaid, an original member of the National Gay and Lesbian Task Force and LIPS, a lesbian activism group from the 1990s, "That was my direct action group!... We made a banner that said, 'Lesbians Protesting Injustice.' And we did lots of participation in different marches, non-gay marches, too, so we would do lesbian visibility, queer visibility. And we always had leaflets. Our motto was, 'We believe in getting the word out (Vaid, as cited in Vogel, 2019)." Here, the transition into direct action is showcased, as members of the 1973 National Gay and Lesbian Task Force had borrowed and learned from her past communities and moved into more active participation in social movements in the 1990s. This marks a departure from communities meeting to sit and discuss issues, as the older task forces and community groups originally did, and instead towards mobilizing and unifying against queer oppression. This is not to say previous task forces never did direct action, as they certainly did, but rather, that direct action had moved into the forefront of queer liberation.

Following the 1990s, there was a significant shift in social attitudes and community conceptualizations of queer liberation. Here, there became a large emphasis on gay marriage and 


\section{QUEER: A 25 YEAR HISTORY}

the subsequent rights that come along with marriage, along with gay identity in public sectors (PBS, 2015). This emphasis stemmed from several court cases in which gay marriage and gay identity was the subject of lawsuits, such as the passing of "Don't Ask Don't Tell” by congress, the murder of Matthew Shephard, or the passing of the Defense of Marriage Act (DOMA) (PBS, 2015.) Each of these cases further signaled the departure of queer activism from merely meeting to discuss movements to mobilizing and taking an active stance against queer oppression.

In unison with this phenomenon, the early 2000 s also seemed to metaphorically pause the radical queer liberation of the 1990s and before, and instead centered gay marriage and the rights to securing queer family structures. This is illustrated by the fact that the early 2000 s marked some of the first court cases that determined gay marriages and unions as legal and that outlawing them was unconstitutional. Cases such as Lawrence v Texas, which ruled sodomy laws in the U.S. as unconstitutional, and when April 26, 2000, marked Vermont as the first state in the U.S. to legalize same-sex civil unions and registered partnerships (PBS, 2015.) It wasn't far behind these cases that in May 2000, Massachusetts became the first state to legalize gay marriage, and in the six years that followed 5 more states came after (PBS, 2015.)

Even in the wake of so much to celebrate, laws limiting and acting against queer people did not come in short quantities. Proposition 8 was passed in California in 2008, making samesex marriage in California illegal. This oppressive law's reign wouldn't end until 2010, and gay marriage wouldn't become legal in all 50 states until 2015, nearly 15 years after the surge of activism and emphasis was put on access to marriage equality and support for queer family structures.

In regards to accessing equal family structures for queer people, there are still outstanding obstacles and oppressive structures that gatekeep same-sex and queer couples from adopting or 


\section{QUEER: A 25 YEAR HISTORY}

having children. Even though same-sex adoption is currently legal in all 50 states as of 2021 , there are state-specific requirements that same-sex couples must meet. These requirements are oftentimes unattainable or especially difficult for these couples to achieve. Furthermore, according to the U.S. Census, $15 \%$ of same-sex households have children in their households, which is only about half the percentage of their heterosexual counterparts. In addition, same-sex couples are more likely to adopt but face statistically more difficult barriers to entry to adopt children (Taylor, 2020.)

Circling back to a point mentioned above, the movement to bring back radical queer liberation and recentering of queer identity would come with the publishing and recentering of queer theory and reintroduction of Black and feminist scholarship in both social and academic settings. In fact, in recent years, according to the National Center for Education Statistics, women and gender studies degrees have increased by over 300\% since the 1990s (National Center for Education Statistics, 2017.) This statistic marks an important shift in queer liberation, as younger generations are shifting their focus away from the early 2000s emphasis on gay marriage and access to family structures, and instead, moving toward more radical and theorybased activism.

As mentioned earlier, one of the key pillars to this thesis, queer theory, and queer history is feminist rhetoric. More specifically, Black feminist rhetoric. As a community, we are learning the necessity and impact that the intersections of the Black Lives Matter, Black liberation, and Black feminist movements have had and continue to have with the recent rise of radical queer activism in the last 5 or so years. In 2021, it has been demonstrated that queer liberation cannot be achieved without acknowledging, working in coalition with, listening to, and learning from Black activism and feminism. This has been demonstrated through the rise in awareness of Black 


\section{QUEER: A 25 YEAR HISTORY}

activist and feminist ideologies as of 2015 to 2021, the highlighting of Black stories and experiences in the news, and a general shift in society towards beginning to unlearn and be actively anti-racist in all that we do as a queer community. While the queer community is in no way a perfect example of anti-racism or the abolishment of racism as a whole social ideology, it does serve as an important starting ground for past, present, and future queer communities and liberation to exist and move forward in dismantling oppressive social systems.

In thinking about the term "queer" in 2021, there is much to be said on the topic. Along with the complex and important information provided above, there is also the fact that queer is an ever-evolving term and is never going to be fully understood or done evolving. While this may seem troubling to some, this stays true to the initial intent of the queer identity, in that it is intentionally ambiguous and works hard to actively include all that wish to claim it. This division is still echoed in the queer community today, as some refer to queer as, "empowering," "reclaimed," and "inclusive," while others feel, "ambivalent," or that queer is reductive to certain members of the community (Cheves, 2019.) These sentiments speak to the very core of the term queer, in that it is and perhaps will always be a divisive term for certain members of the queer community. However, and as shown overall, the term queer serves as an important function for theory, community, and other social identities in our modern world. Without it, there may not be a need for expansion and evolution into future queer activism and politics. Moreover, without the term queer, the community it stands to represent and empower may still be without the inherent empowerment or inclusivity that solely reclaimed terms can afford a community.

Lastly, without the queer identity and term, other areas of academic research and social theory such as linguistics, feminism, and queer theory would cease to expand and extend to the very brink of previous conceptualizations. Queer functions as a unique site to recognize 
shortcomings and pitfalls in previous theory, academic work, and social movements. Here, it pushes those around it to rethink their every thought, move, and emotion along the way for the bettering of their community, whether or not they consider themself queer, a fellow community member, or an ally.

In conclusion, it is imperative to end with the knowledge and understanding that queer is not merely a word or identity, but also a social phenomenon, movement, and reclamation. This term serves as the central point from which queer history, queer futurity, and present-day communities can meet at a unique nexus at which they can co-exist and work in coalition with one another to dismantle and reconfigure the world, and assemble it based on the terms and conditions of the very ones who it has so long oppressed. 
References:

Bronski, M. (2011). A queer history of the United States (Revisioning American history). Boston: Beacon Press.

Cheves, A. (2019, June 4). 9 LGBTQ+ People Explain How They Love, Hate, and Understand the Word "Queer". Them. https://www.them.us/story/what-doesqueer-mean

Crenshaw, K. (2016). The urgency of intersectionality. [Video]. TED.

https://www.ted.com/talks/kimberle_crenshaw_the_urgency_of_intersectionality?languag $\underline{\mathrm{e}=\mathrm{en}}$

Crossman, A. (2020, February, 25). Feminist Theory in Sociology. ThoughtCo. https://www.thoughtco.com/feminist-theory-3026624

Giffney, Noreen, and O'Rourke, Michael. The Ashgate Research Companion to Queer Theory.

Routledge/Taylor \& Francis Group, 2016.

Glick, E. (2000). Sex Positive: Feminism, Queer Theory, and the Politics of Transgression.

Feminist Review, 64(1), 19-45. https://doi.org/10.1080/014177800338936

GLSEN (2016). LGBTQ HISTORY TIMELINE REFERENCE. GLSEN. https://www.glsen.org/sites/default/files/LGBTQ-History-Timeline$\underline{\text { References.pdf }}$

Hall, K. (2013). Commentary I: 'It's a hijra!' Queer linguistics revisited. Discourse \& Society,

24(5), 634-642. https://doi.org/10.1177/0957926513490321 
Harris, K. (2005). Queer theory: Definition \& Literary example. SJSU.

https://www.sjsu.edu/faculty/harris/Eng101_QueerDef.pdf

Hooks, b. (2000). Feminist theory: From margin to center. Pluto Press.

Keywords Project. (2016). The University of Pittsburgh. Retrieved March 18, 2020 from https://keywords.pitt.edu/keywords_defined/queer.html

Killian, K. (2014). Activism, gay poetry, AIDS in the 1980s. Paideuma, 41, 3-19. Retrieved May 20, 2021, from http://www.jstor.org/stable/43908238

Kotz, David. (2003). Neoliberalism and the U.S. Economic Expansion of the '90s. Monthly Review. 54. 17. 10.14452/MR-054-11-2003-04_2.

McRuer, R. (2011). Cripping Queer Politics, or the Dangers of Neoliberalism. $S \& F$ Online. Retrieved April 1, 2021, from http://sfonline.barnard.edu/a-new-queeragenda/cripping-queer-politics-or-the-dangers-of-neoliberalism/

Merriam-Webster. 2020. Queer. In Merriam-Webster.com dictionary. Retrieved from https://www.merriam-webster.com/dictionary/queer\#h2

Motschenbacher, H., \& Stegu, M. (2013). Queer Linguistic approaches to discourse. Discourse \&

Society, 24(5), 519-535. https://doi.org/10.1177/0957926513486069

Myers, J. (2013). Historical dictionary of the lesbian and gay liberation movements: Historical dictionaries of religions, philosophies, and movements series. ProQuest Ebook Central https://ebookcentral-proquest-com.proxy.lib.pdx.edu National Center for Education Statistics. (2017, May 17). USA Today says Women's and Gender Studies is more popular than ever! University of Illinois UrbanaChampaign College of Liberal Arts \& Sciences: Department of Gender and 
Women's Studies. https://gws.illinois.edu/news/2017-03-05/usa-today-sayswomens-and-gender-studies-more-popular-ever

Perlman, M. (2019, January 22). How the word queer was adopted by the LGBTQ community.

Columbia Journalism Review. https://www.cjr.org/language_corner/queer.php

Public Broadcasting Service. (2015-2021). Milestones in the American Gay Rights Movement. American Experience. https://www.pbs.org/wgbh/americanexperience/features/stonewall-milestonesamerican-gay-rights-movement/

Stanger, E. (Host). (2019, June 16). Osunality+Men on cam. (No. 3). [Audio Podcast Episode]. In Strange Bedfellows Podcast. Strange Bedfellows Crew. https://strangebedfellowspdx.com/season-1/2019/6/16/s2-ep3-osunality-men-oncam

Taylor, D. (2020, September 17). Same-Sex Couples Are More Likely to Adopt or Foster Children. United States Census Bureau. https://www.census.gov/library/stories/2020/09/fifteen-percent-of-same-sexcouples-have-children-in-their-household.html

Vogel, J. (2019, July 5). A History of Queer Direct Action. Dissent. https://www.dissentmagazine.org/online_articles/a-history-of-queer-direct-action$\underline{\text { stonewall-fifty-years }}$

Weiss, M. (2018). Queer politics in neoliberal times. Routledge History of Queer America. Retrieved December 1, 2020, from 
QUEER: A 25 YEAR HISTORY

https://www.academia.edu/36691293/Queer_Politics_in_Neoliberal_Times_1970

s_2010s 